\title{
Formation and Fragmentation of Gas-Phase Ion-Molecule Complexes of Transition-Metal Ions with Organic Molecules Containing Two Functional Groups
}

\author{
Lin-Zhi Chen and Jack M, Miller \\ Department of Chemistry, Brock University, St. Catharines, Ontario, Canada
}

A mass spectrometer fast atom bombardment source has been used to synthesize, in the gas phase, the ion-molecule complexes of transition-metal ions $\left(\mathrm{Ni}^{+}, \mathrm{Co}^{+}, \mathrm{Fe}^{+}\right.$, and $\mathrm{Mn}^{+}$) with $\alpha$ - or $\beta$-unsaturated alkenenitriles, $R C H=C H C N\left(R=H, C H_{3}\right.$, and $\left.C_{2} H_{5}\right)$ and $\mathrm{CH}_{3} \mathrm{CH}=\mathrm{CHCH}_{2} \mathrm{CN}$, and 2-methyl glutaronitrile. The metastable ion fragmentations of the complexes are monitored in the first field-free region by $\mathrm{B} / \mathrm{E}$ linked scans. Surprisingly, an intense $\mathrm{HCN}$ loss via an intermediate $\left(\mathrm{C}_{n} \mathrm{H}_{2 n-2}\right)-\mathrm{M}^{+}-(\mathrm{HCN})$ is observed for the complexes of the alkenenitriles. The metal ions significantly affect the fragmentation processes. The coexistence of both end-on and side-on coordination modes is suggested to explain the fragmentations. ( $\mathrm{Am}$ Soc Mass Spectrom 1992, 3, 451-459)

$\mathrm{G}$ as-phase ion-molecule reactions of transitionmetal ions (both positive and negative, including cluster ions) with organic molecules in the gas phase have been an active research area for the last decade [1]. The gas phase is an ideal environment for the study of the intrinsic properties of metal ions in the absence of any complicating solvent effects. Mass spectrometry, such as ion cyclotron resonance (ICR) [2], especially the more recently developed Fourier transform ICR [3], ion beam experiments [4], quadrupole [5], and sector tandem mass spectrometry [6], has been applied to the gas-phase metalion chemistry [7].

Recently, Schwarz and co-workers [8] using a tandem sector mass spectrometer, have investigated the ion-molecule reactions of $\mathrm{Fe}^{+}$with unbranched alkanenitriles and found a selective functionalization of remote $\mathrm{C}-\mathrm{H}$ and/or $\mathrm{C}-\mathrm{C}$ bonds by $\mathrm{Fe}^{+}$in an "end-on" coordination mode I. The remote functionalization has since been extended to other systems like isonitrile [9], amines [10], alcohols [10b, 11], alkynes [12], allenes [13], and ketones [14]. Basically, this involves selective activation of a $\mathrm{C}-\mathrm{H}$ (or $\mathrm{C}-\mathrm{C}$ ) bond a position remote from the $\mathrm{CN}$ functional group, followed by $\beta-\mathrm{H}$ transfer or $\beta$-cleavage of a $\mathrm{C}$ $-\mathrm{C}$ bond which generates $\mathrm{H}_{2}$, alkenes, or alkanes. However, our studies of the transition-metal ions with alkanenitriles $[15,16]$ and phenyl-containing nitriles [17] suggested a coexistence of both "end-on" and "side-on" II coordination modes. When the nitrile

Address reprint requests to Jack M. Miller, Department of Chem istry, Brock University, St. Catharines, Ontario, Canada L2S $3 A 1$. "side-on" II coordination modes. When the nitrile

$$
\begin{array}{cc}
\text { Mode I } & \text { Mode II } \\
\mathrm{R}-\mathrm{C} \equiv \mathrm{N} \cdot-\mathrm{M}^{+} & \mathrm{R}-\mathrm{C} \equiv \mathrm{N} \\
\vdots \\
\mathrm{M}^{+}
\end{array}
$$

chain is long enough, the end-on complexed metal-ion reaction will dominate. For short-chain nitriles (carbon number in the chain of less than 5), the side-on products are formed. Furthermore, end-on versus side-on complexation of the nitrile group is found in the alkenenitrile/metal-ion complexes [18]. For alkenenitriles in which the double bond and nitrile group are separated by four or more methylene groups, the metal ion is complexed in an end-on mode by the nitrile group with the $\mathrm{C}=\mathrm{C}$ double bond as a $\pi$ donor. The alkenenitriles, with less than four methylene groups between both the functional groups, complexes in end-on mode to the metal ion.

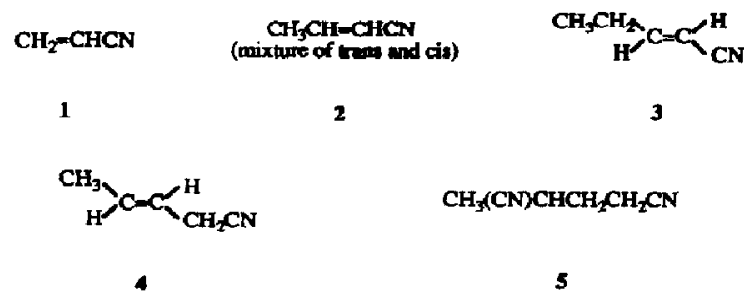

In this article we will show the coexistence of both side-on and end-on complexation of the metal ions $\left(\mathrm{Ni}^{+}, \mathrm{Co}^{+}, \mathrm{Fe}^{+}\right.$, and $\left.\mathrm{Mn}^{+}\right)$with short-chain alken- 
enitriles (1-4) and 2-methylglutaronitrile 5 that contain two functional groups. To set the stage for the discussion of the reaction involving the short-chain alkenenitriles, we summarize the long-chain alkenenitrile reactions reported by Schwarz and co-workers [18]. (1) For systems with $m>2$, the fundamental reaction proceeds via a metal-containing cyclic intermediate 6 and involves the exocyclic allylic $\mathrm{CC}$ bond cleavage to eliminate $\mathrm{RCH}=\mathrm{CH}_{2}$ (Scheme I). (2) Partial migration of the double bond occurs preferentially away from the $\mathrm{CN}$ group. (3) If $\mathrm{m}<2$ ( $\mathrm{R}=$ propyl or butyl), the exocyclic allylic $\mathrm{CC}$ bond cleavage does not dominate any longer. In contrast, the product distribution is typical of that for a saturated nitrile [8], i.e., the chemistry is governed by the functionalization of remote $\mathrm{C}-\mathrm{H}$ bonds by the end-on complexed $\mathrm{Fe}^{+}$.

\section{Experimental}

A Kratos Concept IS double-focusing mass spectrometer of E/B configuration (Kratos Analytical, Urmstom, Manchester, UK) controlled by a Kratos DS 90 Data Cencral Eclipse based computer system was used. A Kratos Mach 3 data system running on a SUN SPARC station was used for further data workup. The normal fast atom bombardment (FAB) source has been modified so that it could accept a reservoir probe as the source of gaseous molecules for sludying ion-molecule reactions. Detailed descriptions of the modified instrument and operating conditions are given elsewhere [15]. Briefly, the instrument was fitted with an Ion Tech (Middlesex, UK) saddle field atom gun. Xenon was used as the fast atom source. The fast atom-beam energy was $8 \mathrm{keV}$ with a density corresponding to an emission current of about $1 \mathrm{~mA}$. The source was operated at a temperature of $25{ }^{\circ} \mathrm{C}$, a pressure of about $10^{-5}$ torr (measured in the source housing, not in the reaction region), and an accelerating voltage of $6 \mathrm{kV}$. Normal mass spectra were

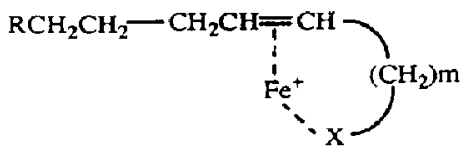

6

$$
-\mathrm{RCH}=\mathrm{CH}_{2}
$$

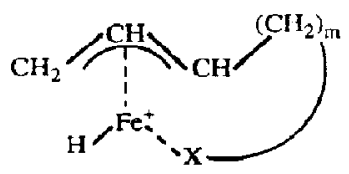

7

Scheme I. Loss of $\mathrm{RCHCH}$, from alkenenitrile/Fe ${ }^{+}$complex $(\mathrm{X}=\mathrm{CN})$. recorded at a resolving power of $\sim 1000$. Metastable ion (MI) or collision-induced dissociations (CID) in the first field-free region were monitored by $B / E$ linked scans. The pressure of the helium collision gas in the collision chamber was maintained so as to reduce the main beam by $20 \%$ (approximately corresponding to 1.1 collisions [19]). Because there was some diffusion from the source into the collision chamber region, metastable ions for recording the MI spectra might have been partially activated. For other systems, however, we observed identical transitions of metastable ions in both the first and the second field-free region.

"Naked" metal ions were generated from $\mathrm{FeSO}_{4}$. $7 \mathrm{H}_{2} \mathrm{O}, \mathrm{CoCl}_{2} \cdot 6 \mathrm{H}_{2} \mathrm{O}, \mathrm{NiCl}_{2} \cdot 6 \mathrm{H}_{2} \mathrm{O}$, and $\mathrm{MnCl}_{2}$. $4 \mathrm{H}_{2} \mathrm{O}$, which had been dissolved in water and deposited by evaporation onto the FAB probe tip. The nitriles were introduced into the source by using the reservoir probe. A $3-\mu \mathrm{L}$ sample of the liquid reagent was injected into the reservoir probe whose highest temperature was $150{ }^{\circ} \mathrm{C}$. All samples were commercially available and used without further purification.

\section{Results and Discussion}

\section{Reactions with Alkenenitriles 1-4}

The ion-molecule reactions of the transition-metal ions $\left(\mathrm{Ni}^{+}, \mathrm{Co}^{+}\right.$, and $\left.\mathrm{Fe}^{+}\right)$with the alkenenitriles 1-4 in the FAB source give monoadduct ions, $\mathrm{RCN}-\mathrm{M}^{+}$, with an intensity (relative to corresponding metal ion) of $15-30 \%$ for $\mathrm{RCN}-\mathrm{Ni}^{+}, 5-13 \%$ for $\mathrm{RCN}-\mathrm{Co}^{+}$, and 1-5\% for $\mathrm{RCN}_{-} \mathrm{Fe}^{+}$. We also observed some fragment ions from the monoadducts. In addition, the dimer ions, $(\mathrm{RCN})_{2} \mathrm{M}^{+}$, form in lower intensities. In contrast, $\mathrm{Mn}^{+}$, under our experimental conditions, gives a less intense monoadduct ion $(\leq 1 \%)$ and no dimer. These relative monoadduct and dimer ion intensities may reflect the binding strength between the metal ions and alkenenitriles [20]. The fragmentation of the monoadduct ions was investigated by means of metastable ion techniques. The following discussion will focus on the MI studies.

The MI spectra of the monoadducts of $\mathrm{Ni}^{+}, \mathrm{Co}^{+}$, and $\mathrm{Fe}^{+}$have an intense peak corresponding to $27 \mu$ loss (Table 1), except for $1-\mathbf{M}^{+}$, which shows only detachment of the ligand. This process dominates the MI spectra of 3- $\mathrm{M}^{+}$and $4-\mathrm{M}^{+}$. Ligand detachment alone is observed for $\mathrm{RCN}-\mathrm{Mn}^{+}$except for $3-\mathrm{Mn}^{+}$, which also shows the loss of $\mathrm{H}_{2}$. The loss of $27 \mu$ is likely linked with the formation of $[\mathrm{M}+27 \mu]^{+}$ion, i.e., both are produced from the same intermediate. High resolution mass measurement of the $[\mathrm{Ni}+27$ $\mu]^{+}$ion demonstrates that its elemental composition is $[\mathrm{Ni}, \mathrm{H}, \mathrm{C}, \mathrm{N}]^{+}$. Therefore, the $27 \mu$ unit is $\mathrm{HCN}$ and the elimination of $\mathrm{HCN}$ should involve a hydrogen transfer to the metal center. HCN loss has been observed for the metal-ion complexes of phenyl-containing nitriles [17] and $\alpha$-branched nitriles [21, 22].

For the conjugated alkenenitrile complexes, $2-\mathrm{M}^{+}$ and $3-\mathrm{M}^{+}, \mathrm{HCN}$ formation seems to involve a simi- 
Table 1. MI spectra of ion-molecule adduct $\mathrm{RCN}-\mathrm{M}^{+}(\mathrm{M}=\mathrm{Ni}, \mathrm{Co}, \mathrm{Fe}, \mathrm{Mn})$

\begin{tabular}{|c|c|c|c|c|c|c|c|c|c|c|}
\hline & \multicolumn{3}{|c|}{$2-M^{+}$} & \multicolumn{4}{|c|}{$3-M^{+}$} & \multicolumn{3}{|c|}{$4-M^{+}$} \\
\hline & $\mathrm{Ni}$ & Co & $\mathrm{Fe}$ & $\mathrm{Ni}$ & Co & $\mathrm{Fe}$ & $M n$ & $\mathrm{Ni}$ & Co & $\mathbf{F e}$ \\
\hline$-2 \mu$ & & & & 47 & 45 & 60 & 22 & & & \\
\hline$-26 \mu$ & & & & & & & & & $<1$ & 2 \\
\hline$-27 \mu$ & 17 & 15 & 10 & 100 & 100 & 100 & & 34 & 100 & 100 \\
\hline$[M+27 \mu]^{+}$ & & & & 47 & 39 & & & 100 & 54 & 4 \\
\hline$[M+41 \mu]^{+}$ & & & & & & & & 41 & 6 & \\
\hline $\mathbf{M}^{+}$ & 100 & 100 & 100 & 32 & 42 & 44 & 100 & & 20 & 20 \\
\hline
\end{tabular}

The abundances of the product ions are normalized to the corresponding base peak.

lar mechanism. One may assume complex formation by an ion/dipole mechanism, which is suggested for the formation of $\mathrm{HCN}-\mathrm{Fe}^{+}$from $t$-butyronitrile $/ \mathrm{Fe}^{+}$ complex [22] and expect that the transition-metal ions are attached to the nitrogen atom of the $\mathrm{CN}$ functional group in end-on form. According to this mechanism, the linked product $\mathrm{M}^{+}[\mathrm{HCN}]$ should have an $\mathrm{HCN}-\mathrm{M}^{+}$structure and give $[\mathrm{M}+\mathrm{N}]^{+}$ion after collisional activation (CA) [22]. For comparison, under the same experimental conditions we have recorded the $\mathrm{CA}$ spectrum of $\mathrm{Fe}^{+}[\mathrm{HCN}]$ ion generated by the reactions of $\mathrm{Fe}^{+}$with $t$-butyronitrile. Ligand detachment is the only process observed. In contrast, the CA spectra of the $[\mathrm{M}, \mathrm{H}, \mathrm{C}, \mathrm{N}]^{+}$ions $^{1}$ formed by the reactions of $\mathrm{M}^{+}(\mathrm{M}=\mathrm{Ni}, \mathrm{Co}$, and $\mathrm{Fe})$ with 3 show $[\mathrm{M}+\mathrm{H}]^{+},[\mathrm{M}+\mathrm{CN}]^{+}$, and $[\mathrm{M}+\mathrm{C}]^{+}$peaks in addition to the simple detachment product ion (Table 2). This result is consistent with a structure of $\mathrm{H}-\mathrm{M}^{+}-\mathrm{CN}$. It is thus not unreasonable to suggest that the elimination of $\mathrm{HCN}$ involves an initial insertion of the metal ion into the $\alpha-\mathrm{C}-\mathrm{CN}$ bond to form an intermediate 9, $\mathrm{RCH}_{2} \mathrm{CH}=\mathrm{CH}-\mathrm{M}^{+}-\mathrm{CN}(\mathrm{R}=\mathrm{H}$ or $\mathrm{CH}_{3}$ ), followed by a hydrogen transfer (see Scheme II). Note that based on a consideration of their stability we assume that the eliminating $[\mathrm{H}, \mathrm{C}, \mathrm{N}]$ species is $\mathrm{HCN}$ from the intermediate $10 \mathrm{~b}$ rather than $[\mathrm{H} \cdot+$ $\cdot \mathrm{CN}]$. In fact, the CA spectra of the $\mathrm{M}^{+} /[\mathrm{HCN}]$ ions are dominated by the loss of $\mathrm{HCN}$ (see Table 2). For 3 $-\mathrm{M}^{+}\left(\mathrm{R}=\mathrm{CH}_{3}, \mathrm{M}=\mathrm{Ni}\right.$, and $\left.\mathrm{Co}\right)$, the $\mathrm{HCN}$ loss is in competition with the formation of $\mathrm{H}-\mathrm{M}^{+}-\mathrm{CN}$ via the loss of $\mathrm{C}_{4} \mathrm{H}_{6}$. Unfortunately, there is not sufficient evidence to identify the origin of the migrating hydrogen and thus the structure of $\mathrm{C}_{4} \mathrm{H}_{6}$. The intermediate $10 a$ is probably a cyclopropene 11 , allene 12 , or alkyne

Table 2. CA spectra of $\mathrm{M}^{+} /[\mathrm{HCN}]$ ions

\begin{tabular}{cccc}
\hline Product ions & $\mathrm{Ni}^{+} /[\mathrm{HCN}]$ & $\mathrm{Co}^{+} /[\mathrm{HCN}]$ & $\mathrm{Fe}^{+} /[\mathrm{HCN}]$ \\
\hline $\mathrm{MH}^{+}$ & 2 & 9 & 17 \\
$\mathrm{MCN}^{+}$ & 12 & 6 & 8 \\
$\mathrm{MC}^{+}$ & 2 & 2 & 3 \\
\hline
\end{tabular}

The product ion abundances are relative to those of $\mathrm{M}^{+}$ions corresponding to the base peaks.

\footnotetext{
${ }^{1} \mathrm{Fe}\left[\mathrm{H}_{r} \mathrm{CN}\right]^{+}$ion is not observed in the metastable fragmentation of $3-\mathrm{Fe}^{+}$adduct, although the inn is formed in the $\mathrm{FAB}$ source. In fact, by $\mathrm{CA}, 3-\mathrm{Fe}^{+}$gives the $\mathrm{Fe}[\mathrm{H}, \mathrm{CN}]^{+}$ion. These results suggest that the formation of the $\mathrm{Fe}[\mathrm{H}, \mathrm{CN}]^{+}$ion involves a higher energy channel.
}

complex 13. In addition, a butadiene complex $(R=$ $\mathrm{CH}_{3}$ ), as well as a metallacycle are two other alternatives. Among these, the cyclopropene complex is not stable and easily undergoes a ring-opening reaction [23]. Therefore, the structure 11 can be excluded. Because $\beta$-hydrogen transfer is very common in these types of reactions, intermediate $\mathbf{1 3}$ formed via a $\beta$-hydrogen transfer after the metal-ion insertion is more energetically favorable $[7 c, 24]$.<smiles>[R]C1C2C(C#N)[Y4]([H])([H])C12</smiles>

11<smiles>[H][Y16](C#N)=CC=C=C</smiles>

12

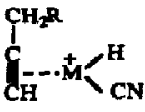

13
It is of interest that the elimination of $\mathrm{HCN}$ has not $\mathrm{RCH}_{2} \mathrm{CH}=\mathrm{CH}-\mathrm{CN} / \mathrm{M}^{+}$

$8\left(\mathrm{R}=\mathrm{H}\right.$ or $\left.\mathrm{CH}_{3}\right)$<smiles>CC(C)CO</smiles>

$\mathrm{RCH}_{2} \mathrm{CH}=\mathrm{CH}-\mathrm{M}^{+}-\mathrm{CN}$

9

H transfer

$\mathrm{H}-\mathrm{M}^{+}-\mathrm{CN}$

$\left[\mathrm{RC}_{3} \mathrm{H}_{3}\right]$

$10 \mathrm{a}$

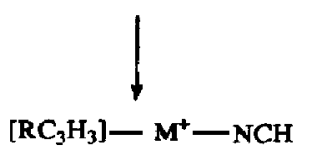

$10 \mathbf{b}$

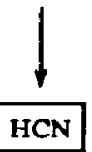

Scheme II. HCN loss from alkenenitrile/metal-ion complex. 
been observed for long-chain alkenenitrile/metal-ion complexes ( $R \geq$ butyl for 8 in Scheme II) [18]. The difference may be explained in terms of coordination mode. Schwarz and co-workers [18] suggested three possible structures for the alkenenitrile $/ \mathrm{Fe}^{+} \mathrm{com}$ plexes. When the double bond and the $\mathrm{CN}$ group are separated by two or more methylenes, a bidentate complex 14 with a side-on coordination of the $\mathrm{CN}$ group by $\mathrm{Fe}^{+}$may be the most favorable. This is perhaps due to the fact that the combined effects of two $\pi$-bonds to $\mathrm{Fe}^{+}$are energetically more favored than $\sigma$ complexation by the nitrogen lone pair (15). If the chain length separating the $\mathrm{CN}$ group and the double bond increases, the structure may be best described by the structure 16. Based on these assumptions, the alkenenitriles 1-4 should coordinate to the metal ion with a structure such as 15. However, the approximately linear combination of the atoms in $\mathbf{1 5}$ keeps the metal ion far from the chain as in alkanenitrile/metal-ion complexes. In this case, the end-on complexed metal ion can only attack the $\mathrm{C}-\mathrm{C}$ or $\mathrm{C}-\mathrm{H}$ bonds further out than the $\omega$ position [8]. Obviously, structure 15 cannot account for the $\alpha$ $\mathrm{C}-\mathrm{CN}$ insertion (See Scheme II). We thus suggest another coordination mode, side-on mode 17 , because the side-on complexed metal ion is close enough to the $\alpha-\mathrm{C}-\mathrm{CN}$ bond so as to be able to insert. Side-on coordination has been suggested for the complexation of transition-metal ions with phosphaalkynes [25] and specially for $\mathrm{Cu}^{+}$reacting with nitriles [26].

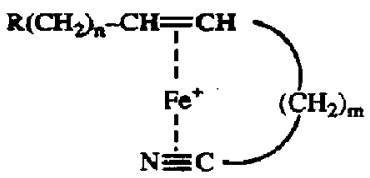

$14(m=2,3,4)$

$\mathrm{R}\left(\mathrm{CH}_{2}\right)_{\mathrm{n}}-\mathrm{CH}=\mathrm{CH}-\left(\mathrm{CH}_{2}\right)_{\mathrm{m}}-\mathrm{CN}---\mathrm{Fe}^{+}$

$15(m=0,1)$

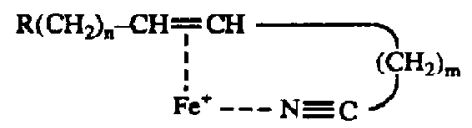

$16(m \geq 4)$

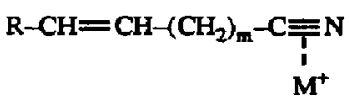

$17(m=0,1)$

It seems that there is coexistence of both end-on and side-on coordination modes for the $\alpha$ - or $\beta$-unsaturated alkenenitrile complexes. Due to the higher stability of the end-on structure than the side-on, the main coordination mode is expected to be the end-on. When the alkenenitrile chains is long enough, for example, with a nitrile with $n=6$ and $m=0$ in 15 , the end-on complexed metal ion selectively attacks the terminal $\mathrm{C}-\mathrm{C}$ and $\mathrm{C}-\mathrm{H}$ bond to give the end-on products [18]. In fact, the end-on decomposition product, $\mathbf{H}_{2}$, is already observed for $3-\mathbf{M}^{+}$complexes. This reaction is described, by 5 chwarz and co-workers, in terms of $\omega-\mathrm{C}-\mathrm{H}$ insertion $/ \beta-\mathrm{H}$ transfer/elimination of $\mathrm{H}_{2}$. However, an $\alpha$ - or $\beta$-unsaturated linear alkenenitrile consisting of less than five carbon atoms produces only the side-on products such as HCN in addition to the detachment. This is similar to the metal-ion complexes of phenyl-containing ritriles [17]. The coexistence of both end-on and side-on modes has been suggested for the metal-ion complexes of alkanenitriles $[15,16]$ and alkaneisonitriles [9].

For the complexes of $4-\mathrm{M}^{+}, \mathrm{Ni}^{+}$gives a different MI spectrum than $\mathrm{Fe}^{+} . \mathrm{Co}^{+}$shows characteristics of both (see Table 1). The base peak in the MI spectrum of $4-\mathrm{Ni}^{+}$corresponds to $[\mathrm{Ni}+27 \mu]^{+}$ion. In addition, peaks corresponding to the loss of HCN and $[\mathrm{Ni}+41 \mu]^{+}$ion are also present. No ligand detachment is observed. In contrast, for $4-\mathrm{Fe}^{+}$, the $\mathrm{HCN}$ loss is the most important and the $[\mathrm{Fe}+27 \mu]^{+}$peak becomes less abundant. The different behavior between complexed $\mathrm{Ni}^{+}, \mathrm{Co}^{+}$, and $\mathrm{Fe}^{+}$has been noted for the complexes of phenyl-containing nitriles [17].

The $[\mathrm{Ni}+27 \mu]^{+}$ions formed by the reactions of $\mathrm{Ni}^{+}$with either of 3 or 4 give the same CA spectrum, suggesting that they have the same structure $\mathrm{H}-\mathrm{M}^{+}$ $-\mathrm{CN}^{2}$. These results indicate that the $\alpha-\mathrm{C}-\mathrm{CN}$ insertion is again involved in the formation of $\mathrm{HCN}$ and $\mathrm{H}$ $-\mathrm{M}^{+}-\mathrm{CN}$ (Scheme III). This is similar to the ionmolecule reactions of the metal ions with alkenes [27]. A hydrogen transfer then occurs to produce a butadiene cyano complex 20 from which either $\mathrm{HCN}$ or butadiene is eliminated. A $\beta-\mathrm{H}$ transfer in $\mathbf{1 8}$ may also occur to yield methyllene complex, which accounts for retaining or losing $\mathrm{HCN}$. The insertion of metal ions into $\mathrm{C}_{\mathrm{sp3}}{ }^{-} \mathrm{CN}$ bond of nitriles has been recently reported $[17,21,28]$.

Retaining versus losing $\mathrm{HCN}$ for both $3-\mathrm{M}^{+}$and 4 $-\mathrm{M}^{+}$depends on the metal ions. As shown in Table 2 , one can see that the ability of the metal ions for retaining $\mathrm{HCN}$ follows the order: $\mathrm{Ni}^{+}>\mathrm{Co}^{+}>\mathrm{Fe}^{+}$. This order implies that the relative bonding energies, $\mathrm{D}\left(\mathrm{RNi}^{1}-\mathrm{NCH}\right)$ compared to $\mathrm{D}\left(\mathrm{R}-\mathrm{Ni}{ }^{1} \mathrm{NCH}\right)$ are greater than $\mathrm{D}\left(\mathrm{RFe}^{+}-\mathrm{NCH}\right)(\mathrm{R}=$ unsaturated hydrocarbons, see Schemes II and III). Except for $4-\mathrm{Ni}^{+}, 3$

\footnotetext{
${ }^{2}$ It is well known that $C A$ presents a probe with stable ions being investigated, because in a CA process the ion upon collision is a stable species of low internal energy. However, it should be noted that the possibility of rearrangement prior to fragmentation in a CA process can not be completely neglected, because the time spent by the ions to reach the collision zone is long enough for rearrangement.
} 
<smiles>CC=CCC#N</smiles><smiles>CC=C(C[Y10]#N)C(C)C(C)(C)C</smiles>

18<smiles>[H][Y10]([H])=CC(C)CCC</smiles><smiles></smiles>

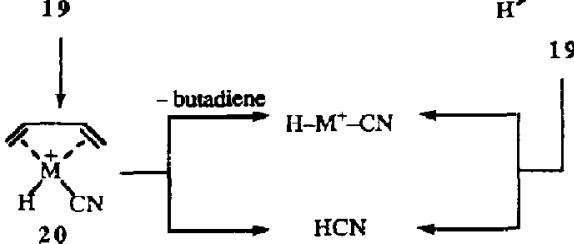

Scheme III. HCN loss from complex 4- $\mathrm{M}^{+}$.

$-\mathrm{M}^{+}$and $4-\mathrm{M}^{+}$prefer to lose $\mathrm{HCN}$. Although most of the energies of the $\mathrm{HCN}-\mathrm{M}^{+}$and $\mathrm{R}-\mathrm{M}^{+}$bonds have not been measured, it is believed that these bond energies correlate with corresponding proton affinities [29]. Molecules with greater proton affinities bond more strongly with the metal ions. In fact, the unsaturated hydrocarbons have greater proton affinities than $\mathrm{HCN}$ [30]. The intense loss of $\mathrm{HCN}$ from $3-\mathrm{M}^{+}$and $4-\mathrm{M}^{+}$is thus understandable.

Finally, the $[\mathrm{Ni}+41 \mathrm{u}]]^{+}$ion produced from $4-\mathrm{Ni}^{+}$ deserves comment. Although high resolution mass measurement fails to provide its elemental composition due to low ion intensity, this ion is likely a complex $\mathrm{CH}_{3} \mathrm{CN}-\mathrm{Ni}^{+}$or $\mathrm{CH}_{3}-\mathrm{Ni}^{+}-\mathrm{CN}$. The $\mathrm{CA}$ spectrum of this ion gives $\mathrm{NiCN}^{+}$and $\mathrm{Ni}^{+}$ions, similar to that of reference ion $\mathrm{CH}_{3} \mathrm{CN}-\mathrm{Ni}^{+}$synthesized in the source by the reaction of $\mathrm{Ni}^{+}$with $\mathrm{CH}_{3} \mathrm{CN}$ [15]. This suggests that the $[\mathrm{Ni}+41 \mu]^{+}$ion is probably the complex $\mathrm{CH}_{3} \mathrm{CN}-\mathrm{Ni}^{+}$. Note the other candidate, $\mathrm{CH}_{3}-\mathrm{Ni}^{+}-\mathrm{CN}$, cannot be completely precluded because it may also produce $\mathrm{NiCN}^{+}$ion after CA. Furthermore, although initial complexation of metal ions with molecules are, in most cases, not clear, metal-ion insertion into a polar bond is very common in the gas phase [31]. Formation of the $\mathrm{CH}_{3} \mathrm{CN}-\mathrm{Ni}^{+}$complex may involve a $\mathrm{\beta}-\mathrm{C}-\mathrm{C}$ insertion of $\mathrm{Ni}^{+}$followed by a hydrogen transfer to the metal center, similar to the mechanism suggested in Scheme $\amalg$. No analogous $\mathrm{CH}_{3} \mathrm{CN}-\mathrm{Fe}^{+}$ion is observed. These results reveal a preference of the insertion of complexed $\mathrm{Fe}^{+}$into the $\alpha-\mathrm{C}-\mathrm{C}$ bond over the $\beta-C-C$ bond.
It is interesting to compare the metastable fragmentation of the alkenenitrile-metal complexes with corresponding alkaneritrile-metal complexes. The $\alpha$ $\mathrm{C}-\mathrm{CN}$ insertion that dominates the MI spectra of the alkenenitrile-metal ions is completely absent for butyronitrile and valeronitrile complexes [16]. The difference arises mainly from coordination mode and reaction thermodynamics. In both systems both the side-on and the end-on coordination coexist. For the alkenenitriles, however, when metal ions are connected to the cyano group in the side-on mode, interaction between the metal ions and the $C=C$ bond stabilizes the coordination [32]. The side-on coordination that accounts for the $\alpha \mathrm{C}-\mathrm{CN}$ insertion is thus more favorable for the alkenenitriles than for the alkanenitriles. On the other hand, metal-ion insertion into an $\alpha \mathrm{C}-\mathrm{CN}$ bond of the alkenenitriles forms allylic intermediates and appears to be energetically more accessible [33].

\section{Reactions with 2-Methylglutaronitrile}

Table 3 gives the MI spectra of the $5-\mathrm{M}^{+}$complexes. If these data are compared with n-pentanenitrile/ $\mathrm{M}^{+}$ where more than $96 \%$ of the fragmentation is due to the losses of $\mathrm{H}_{2}(75 \%)$ and $\mathrm{C}_{2} \mathrm{H}_{4}(21 \%)$ [34], it is obvious that the presence of the second $\mathrm{CN}$ functional group dramatically induces additional fragmentation. Moreover, we do not observe the hydrogen loss that should be generated by the remote functionalization of end-on complexed metal ions. These results are similar to those obtained by Schwarz and co-workers [35] for the complexes of $\mathrm{Fe}^{+}$glutaronitrile where the ethylene loss is the most important fragmentation process. It is thus not unreasonable to consider that among the possible coordination modes $\left(\mathbf{a}, \mathbf{a}^{\prime}, \mathbf{b}, \mathbf{c}, \mathbf{c}^{\prime}\right.$ or d) the two $\pi$-bond structure $d$ is the preferred arrangement.

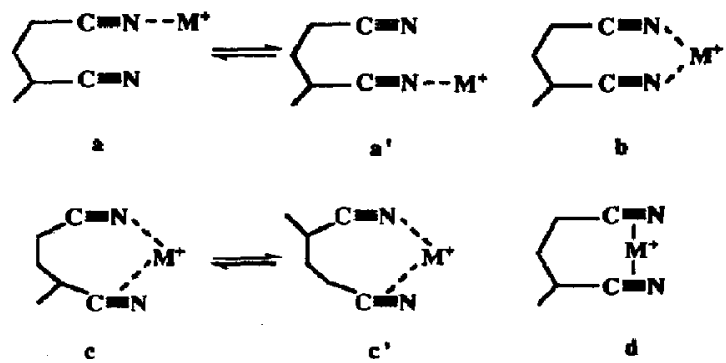

As in the case of alkenenitrile/metal-ion system, complexation in mode $\mathbf{d}$ rather than $\mathbf{a}$ or $\mathbf{a}^{\prime}$ is due to the fact that the combined effects of the two $\pi$-bonds to $\mathrm{M}^{+}$are energetically more favored than the $\sigma$ complexation by the nitrogen lone pair. Structures $b$, c, and $c^{\prime}$ must contain considerable ring strain because of the approximately linear $-\mathrm{CN}-\mathrm{M}^{+}$combination in an end-on mode, and are thus energetically unfavorable. Furthermore, we show below that the 
Table 3. MI spectra of ion-molecule complexes $5-\mathrm{M}^{+}$ $(\mathrm{M}=\mathrm{Ni}, \mathrm{Co}, \mathrm{Fe}$, and $\mathrm{Mn}$ )

\begin{tabular}{lrrrr}
\hline Neutral loss & $5-\mathrm{Ni}^{+}$ & $\mathbf{5}-\mathrm{Co}^{+}$ & $5-\mathrm{Fe}^{+}$ & $\mathbf{5}-\mathrm{Mn}^{+}$ \\
\hline \hline $\mathrm{CH}_{3}{ }^{\cdot}$ & 24 & 25 & 22 & \\
$\mathrm{CN} \cdot$ & 3 & 3 & 7 & \\
$\mathrm{HCN}$ & 100 & 100 & 40 & \\
$\mathrm{C}_{2} \mathrm{H}_{4}$ & 69 & 44 & 59 & \\
$\mathrm{NCCH}_{2}{ }^{\cdot}$ & & 4 & 25 & \\
$\mathrm{CH}_{3} \mathrm{CN}$ & 24 & 35 & 100 & \\
$\mathrm{C}_{3} \mathrm{H}_{6}$ & & 5 & 83 & \\
$\mathrm{C}_{3} \mathrm{H}_{3} \mathrm{~N}$ & 50 & 28 & 33 & \\
$\mathrm{C}_{3} \mathrm{H}_{4} \mathrm{~N}$. & 16 & 3 & 14 & 7 \\
$\mathrm{C}_{3} \mathrm{H}_{5} \mathrm{~N}$ & 36 & 19 & 13 & \\
Detachment & 3 & 17 & 39 & 100 \\
\hline
\end{tabular}

Abundances are normalized to the base peaks.

structure $\mathbf{d}$ is consistent with the fragmentations observed for the $5-\mathrm{M}^{+}$complexes. However, because metastable ions contain significant amounts of internal energy, all of the possible structures may be present, although structure $d$ is the most favorable.

The effects of the metal ions on the fragmentations are distinct. $\mathrm{Fe}^{+}$is more reactive than $\mathrm{Ni}^{+} . \mathrm{Co}^{+}$is intermediate. In contrast, $5-\mathrm{Mn}^{+}$mainly undergoes ligand detachment producing $\mathrm{Mn}^{+}$, revealing a much lower reactivity of $\mathrm{Mn}^{+}$. The relative reactivity has been explained by Babinec and Allison [36b] in terms of promotion energy. When a metal ion inserts into a single bond of an organic molecule to form two $\sigma$ bonds, the metal ion has to be in a configuration in which two electrons are not in $d$ orbitals. The promotion energy required to achieve this configuration falls in the order, $\mathrm{Mn}^{+}>\mathrm{Ni}^{+}>\mathrm{Co}^{+}>\mathrm{Fe}^{+}$. These promotion energies are believed to correlate with the metal ion reactivity. Among the four metal ions, $\mathrm{Fe}^{+}$has the lowest promotion energy and shows a high reactivity.

Based on the structures of the product ions elucidated by $\mathrm{CA}$, we propose the following fragmentation mechanisms of $5-\mathrm{M}^{+}$in Scheme IV. Our discussion focuses on the identification of the major product ion structures and their formation mechanisms.

Loss of HCN. As shown in Table 3 , the loss of HCN constitutes the base peaks of the MI spectra of $5-\mathrm{Ni}^{+}$ and $5-\mathrm{Co}^{+}$. Insertion of $\mathrm{Fe}^{+}$into the $\alpha \mathrm{C}-\mathrm{CN}$ bond followed by $\beta-\mathrm{H}$ transfer is suggested to explain the $\mathrm{HCN}$ loss from glutaronitrile- $\mathrm{Fe}^{+}$complex [35]. As in the case of alkenenitriles discussed above, the $\alpha \mathrm{C}$ $-\mathrm{CN}$ insertion indicates that the initial complexation concerns a side-on coordination. Although both of the $\mathrm{C}-\mathrm{CN}$ bonds in 5 may be involved in the insertion process, the $\mathrm{C}-\mathrm{CN}$ bond containing the secondary $\mathrm{CN}$ group is more likely because it corresponds to a dicoordinated product ion $\mathbf{2 3}$ that is more stable than the ions generated via the other $\mathrm{C}-\mathrm{CN}$ bond insertion (see Scheme IV).
In contrast with 2-methylbutyronitrile/ $/ \mathrm{Fe}^{+}$, where the $\mathrm{C}-\mathrm{CN}$ bond insertion is followed by a $\beta-\mathrm{H}$ and a methyl transfer to the metal center to eliminate methane and methyl radical $[21,29], \mathrm{HCN}$ is eliminated from $5-\mathbf{M}^{+}$after the $\beta-\mathrm{H}$ migration. Formally, the $\beta$-hydrogen may originate from the terminal methyl group or from the internal methylene group. respectively producing complex 23 or $\mathrm{CH}_{3} \mathrm{CH}=$ $\mathrm{CHCH}_{2} \mathrm{CN} / \mathrm{M}^{+}\left(4-\mathrm{M}^{+}\right)$. However, the CA spectrum of the product ion formed via the loss of $\mathrm{HCN}$ from 5 $-\mathrm{Ni}^{+}$is quite different from that of $4-\mathrm{Ni}^{+}$(Scheme $V)$. This is also due to the stability of the product ion 23 with the two $\pi$-bonds. Similarly, the HCN loss from $5-\mathrm{Fe}^{+}$produces ion 23 rather than $4-\mathrm{Fe}^{+}$.

Losses of $\mathrm{C}_{2} \mathrm{H}_{4}$ and $\mathrm{C}_{3} \mathrm{H}_{3} \mathrm{~N}$. CA of the product ion 32, formed via loss of $\mathrm{C}_{2} \mathrm{H}_{4}$ from $5-\mathrm{Fe}$, produces $\mathrm{Fe}^{+}\left(\mathrm{CH}_{2}=\mathrm{CHCN}\right)(100 \%), \mathrm{Fe}(\mathrm{CN})^{+}(6 \%)$, and $\mathrm{Fe}^{+}$ (3\%). This result is consistent with the proposed structure 32. The formation mechanism is expected to involve consecutive insertion into the $\mathrm{C}(4)-\mathrm{CN}$ and $C(2)-C(3)$ bonds (or $C(2)-C(3)$ and $C(4)-C N$ ) to form an intermediate 31 , as in the case of $n$-pentanenitrile $/ \mathrm{Fe}^{+}$. However, for the n-pentanenitrile $/ \mathrm{Fe}^{+}$complex, $\mathrm{Fe}^{+}$first inserts into the $\mathrm{C}-\mathrm{CH}_{3}$ bond and then further into the $\mathrm{C}-\mathrm{CN}$ bond. In fact, the insertion into the $\mathrm{C}-\mathrm{CH}_{3}$ bond is also observed for $5-\mathbf{M}^{+}\left(5-\mathbf{M}^{+} \rightarrow 38\right)$, but the subsequent fragmentation is only via the elimination of $\mathrm{CH}_{3}$.

From the intermediate 31 , a $\beta-\mathrm{H}$ transfer takes place. A cyano ethylene complex 34 then forms after the loss of $\mathrm{CH}_{2}=\mathrm{CHCN}$. Supporting the proposed structure, the CA spectra of $34(\mathrm{M}=\mathrm{Ni}$ and $\mathrm{Fe}$ ) show an $\mathrm{M}(\mathrm{HCN})^{+}$ion peak in addition to the metal ion peak.

Losses of $\mathrm{CH}_{3} \mathrm{CN}$ and $\mathrm{C}_{3} \mathrm{H}_{6}$. The loss of $\mathrm{CH}_{3} \mathrm{CN}$ can be simply considered as the result of a direct $C(3)-C(4)$ bond insertion of the metal ions followed by a $\beta$-H transfer $(\mathbf{2 6} \rightarrow \mathbf{2 7})$, a traditional mechanism of complexed metal ions with organic molecules [7c]. This process produces $\alpha$-methylpropenenitrile $/ \mathrm{M}^{+} 28$. Except for ligand loss, no structure-characteristic products are given by the CA of 28. We thus compare it with the $\mathrm{CH}_{2}=\mathrm{CHCN} / \mathrm{M}^{+}$complex. In fact, due to the unfavored oxidative addition of the vinyl $\mathrm{C}-\mathrm{H}$ or $\mathrm{C}-\mathrm{C}$ bonds to the metal ions, the CA spectrum of the reference complex also shows solely the ligand detachment.

The complexed metal ions in the intermediate 26 can also insert into the $\mathrm{C}(2)-\mathrm{CN}$ bond, forming a cyano propene complex 24 that eliminates propene to generate ion 25 . The structure of 25 is identified by its CA spectrum, which shows $\mathrm{M}^{+}(\mathrm{CN})$ ion peak (loss of $\cdot \mathrm{CH}_{2} \mathrm{CN}$ ). The reaction sequence for the formation of 25 may start with the first insertion of the metal ions into the $\mathrm{C}(2)-\mathrm{CN}$ bond followed by insertion into the $\mathrm{C}(3)-\mathrm{C}(4)$ bond. 


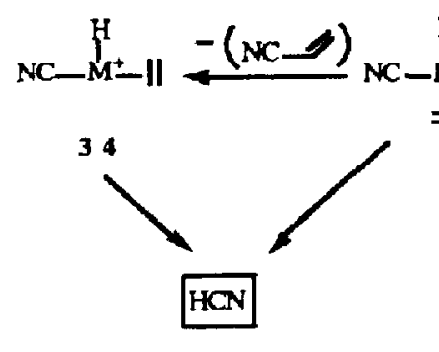<smiles>C[Mg]C(C)N=C(C)C</smiles>

30

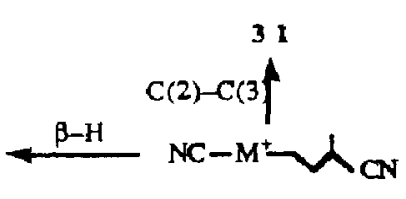

29

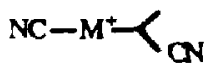

32<smiles>C=CC=[W]</smiles>

37

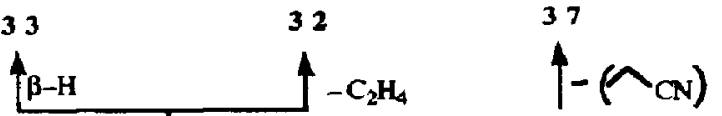

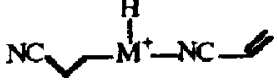

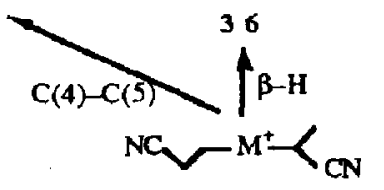

35

$\mathrm{C}(2)-\mathrm{C}(3)$

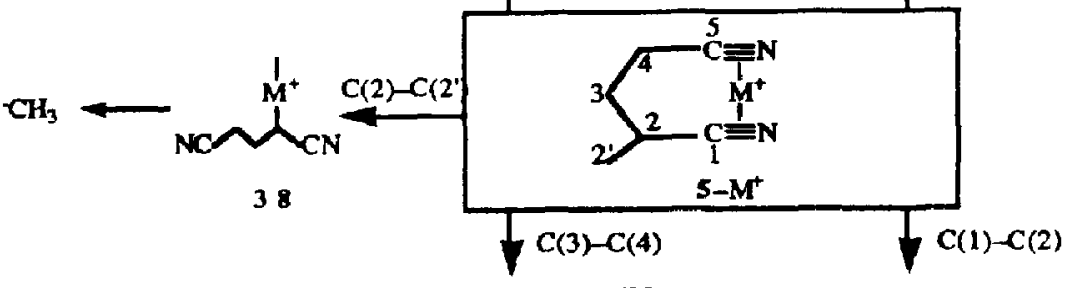

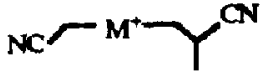

26

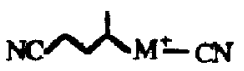

21

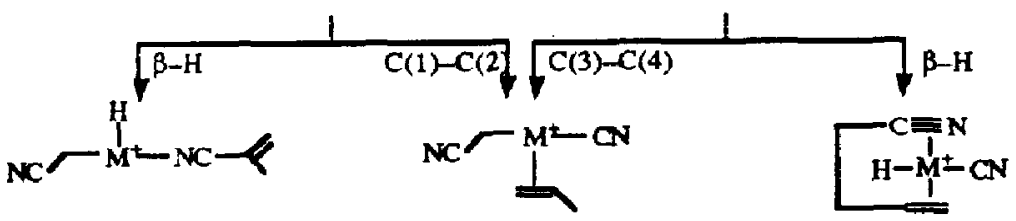

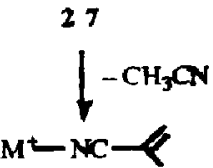

28<smiles>[CH][Y14](C#N)(C#N)C(C)C=CC</smiles>

25

Scheme IV. Fragmentation mechanisms of $5-\mathrm{M}^{+}$complexes.

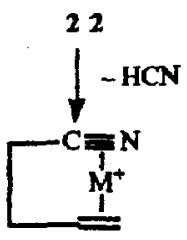

23
Formation of the other product ions are simply described by metal ion insertion $/ \beta-H$ transfer (or $\beta-C$ $-C$ bond cleavage)/competitive ligand elimination. Although all the $\mathrm{Fe}^{+}, \mathrm{Co}^{+}$, and $\mathrm{Ni}^{+}$ions show poor selectivities for the insertion, differences in product distribution are unambiguous. Loss of HCN is the most important reaction for $5-\mathrm{Ni}^{+}$and $5-\mathrm{Co}^{+}$while $5-\mathrm{Fe}^{+}$prefers to lose $\mathrm{CH}_{3} \mathrm{CN}$. That is, $\mathrm{Fe}^{+}$is more likely to insert into $\beta \mathrm{C}-\mathrm{CH}_{2} \mathrm{CN}$ bond while $\mathrm{Ni}^{+}$and $\mathrm{Co}^{+}$insert into $\alpha \mathrm{C}-\mathrm{CN}$ bond. The $\mathrm{C}-\mathrm{CN}$ bond is about $46 \mathrm{kcal} / \mathrm{mol}$ stronger than the $\mathrm{C}-\mathrm{CH}_{2} \mathrm{CN}$ bond
[37]. According to the correlation of reactivity with promotion energy. $\mathrm{Fe}^{+}$should insert into the $\alpha$ $\mathrm{C}-\mathrm{CN}$ bond more easily than does $\mathrm{Ni}^{+}$or $\mathrm{Co}^{+}[36]$. However, this is not the case. The preference of $\mathrm{Fe}^{+}$ for inserting into the $\beta \mathrm{C}-\mathrm{CH}_{2} \mathrm{CN}$ bond is thus probably due to forming a thermodynamically stable insertion intermediate 26 . These results suggest that the relative energies of both the $\mathrm{Fe}^{+}-\mathrm{C}$ bonds in 26 compared to thase in the corresponding $\alpha \mathrm{C}-\mathrm{CN}$ insertion intermediate 21 are greater than those for $\mathrm{Ni}^{+}$and $\mathrm{Co}^{+}$. 


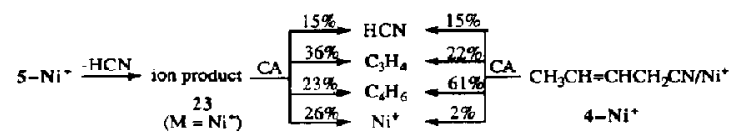

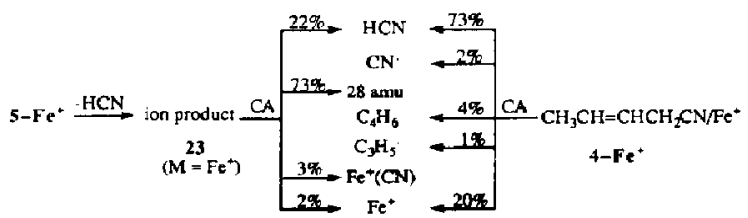

Scheme $V$. Comparison between CA spectra of product ions from 5- $\mathrm{M}^{+}$via $\mathrm{HCN}$ loss and $4-\mathrm{M}^{+}(\mathrm{M}=\mathrm{Ni}$ and $\mathrm{Fe})$.

\section{Conclusions}

1. Both the end-on $\sigma$ and side-on $\pi$ coordination modes seem to coexist in the complexation of $\alpha$ or $\beta$ unsaturated alkenenitriles with the transition-metal ions. As the chain gets longer (e.g., in the case of 3), the end-on decomposition product ion $\mathrm{H}_{2}$ becomes detectable. For the complexes of 2-methyl glutaronitrile 5, bis(side-on) coordination is probably more stable than the other possible modes. Furthermore, the fragmentation of $5-\mathrm{M}^{+}$is consistent with the proposed biscoordination.

2. Some interesting fragmentations are observed for the complexes of the alkenenitriles. Competition between $\mathrm{HCN}$ elimination and $\mathrm{H}-\mathrm{M}^{+}-\mathrm{CN}$ formation is the most important factor for the metastable fragmentations of the monoadducts of 3 and $4 . \mathrm{Ni}^{+}$ and $\mathrm{Co}^{+}$prefer to retain $\mathrm{HCN}$ compared to $\mathrm{Fe}^{+}$. The difference is explained by the relative bond energies. These reactions can be described in terms of $\alpha-C-C N$ insertion of a side-on complexed met ion, rather than ion-dipole mechanism.

3. Metastable fragmentations of the complexes of the bifunctional nitriles are significantly affected by the metal ions. Different characteristics between $\mathrm{Ni}^{+}$ and $\mathrm{Fe}^{+}$are distinct. For example, $5-\mathrm{Ni}^{+}$prefer to eliminate $\mathrm{HCN}$, whereas $5-\mathrm{Fe}^{+}$eliminates $\mathrm{CH}_{3} \mathrm{CN}$ and $\mathrm{C}_{3} \mathrm{H}_{6}$. Relative strengths of $\mathrm{Fe}^{+}$-alkyl versus $\mathrm{Co}^{+}-$alkyl and $\mathrm{Ni}^{+}-$alkyl bonds account for the different product distribution. It should be noted that Armentront and Beauchamp [38] have reported that product distribution also depends on lifetimes of reaction intermediates. As the lifetime decreases, or the intermediate gets more energetic, thermodynamic decomposition becomes possible. Different fragmentation might be observed if the experimental conditions such as collision gas pressure and accelerating voltage are changed. In fact, we have investigated the decomposition under CA conditions. We observed some additional products, but the product ions observed already in metastable fragmentation remained the most important. We also considered measurements at different voltages but sensitivity drops too fast at reduced accelerating potentials.

\section{Acknowledgments}

The authors thank the Natural Sciences and Engineering Research Council of Canada for operating and equipment grants to J. M. Miller and thank T. R. B. Jones and D. Vukmanic for experimental assistance. We are very grateful to the reviewers for helpful suggestions.

\section{References}

1. (a) Farrar, J. M.; Saunder, W. H. Ir., Eds. Techniques for the Study of Ian-Molecule Reaction; Wiley: New York, 1988. (b) Russell, D. H., Ed. Gas-Phase Inorganic Chemistry Plenum: New York, 1989.

2. (a) Allison, J.; Freas, R. B.; Ridge, D. P. J. Am. Chem. Soc. 1979, 101, 1332. (b) Frease, R. B.; Ridge, D. P. Ibid. 1980, 102, 7129. (c) Byrd, G. D; Burnier, R. C.; Freiser, B. C. Tbid. 1982, 104, 3565. (d) Kappes, M. M.; Staley, B. H. Ibid. 1982, $104,1813$.

3. (a) Jacobson, D. B.; Freiser, B. S. J. Am. Chem. Soc. 1983, 105, 736. (b) Jacobson, D. B.; Freiser, B. S. Ibid. 1983, 105, 5197. (c) Jacobson, D. B.; Freiser, B. S. Ibid. 1983, 105, 7492. (d) Jacobson ,D. B.; Freiser, B. S. Organometallics 1984, 3, 513. (e) Jacobson, D. B.; Freiser, B. S. J. Am. Chem. Soc. 1985, 107, 72. (f) Jacobson, D. B.; Freiser, B. S. Ibid. 1985. 10/, 1581.

4. (a) Armentrout, P. B.; Beauchamp, J. L. J. Am. Chem. Soc, 1981, 103, 784. (b) Armentrout, P. B.; Beauchamp, J. L. Tbid. 1981, 103, 6628. (c) Halle, L. F.; Houriet, R.; Kappes, M. M.; Staley, R. H.; Beauchamp, J. L. Ibid. 1982, 104, 6293. (d) Halle, L. F.; Armentrout, P. B.; Beauchamp, J. L. Organometallics 1982, 1, 963. (c) Houriet, R.; Halle, L. F.; Beauchamp, J. L. Ibid. 1983, 2, 1818. (f) Tolbert, M. A.; Beauchamp, J. L. J. Am. Chem. Soc. 1984, 106, 8117.

5. Mestdagh, H.; Morin, N.; Rolando, C. Tetrahedron Lett. $1986,27,33$

6. (a) Eller, K.; Schwarz, H. Int. J. Mass Spectrom. Ion Proc. 1989, 93, 243. (b) MacMill, D. K.; Gross, M. L. In Gas-Phase Inorganic Chemistry; Russell, D. H., Ed.; Plenum: New York, 1989; p 369. (c) Eller, K.; Schwarz, H. Chem. Ber. 1990, 123, 201. (d) Hasselbrarth, A.; Prusse, T.; Schwarz, H. Chem. Ber. 1990, 123, 213.

7. (a) Schwarz, H. Acc. Chem. Res. 1989,22, 282. (b) Czekay, G.; Drewella, T.; Eiler, K.; Lebrilla, C. B.; Prusse, T.; Schulze, C.; Steinruck, S.; Sulzle, D.; Weiske, T.; Schwarz, H. In Organometallics in Organic Symthesis, vol. 2; Werner, H.; Erker, G., Eds.; Springer Verlag: Heidelberg, 1989; $p$ 203. (c) Allison, J. Prog. Inorg. Chem, 1986, 34, 627. (d) Crabtree, R. H. Chem. Rev. 1985, 85, 245. (e) For negative ion reaction, see Gregor, I. K.; Guilhaus, M. Mass Spectrom. Rev. 1984, 3, 39. (f) Freiser, B. S. Chemtracts-Ana. and Phys. Chem. 1989, $I, 65$. (g) Armentrout, P. B.; Beauchamp, J. L. Acc. Chem . Res. 1989, 22, 315.

8. (a) Lebrilla, C. B; Schulze, C.; Schwarz, H. J. Am. Chem. Soc. 1987, 109, 98 . (b) Lebrilla, C. B.: Drewello, T.; Schwarz, H. Tbid. 1987, 109, 5639. (c) Lebrilla, C. B.; Drewello, T.; Schwarz, H. Int, J. Mass Spectrom. Ion Proc. 1987, 79, 287.

9. Eller, K.; Lebrilla, C. B; Drewello, T.; Schwarz, H. I. Am. Chem. Soc. 1988, 110, 3098.

10. (a) Karrass, S.; Eller, K.; Schulze, C.; Schwarz, 11. Angew. Chem. Int. Ed. Engl. 1989, 28, 607. (b) Karrass, S.; Prusse, T.; Eller, K.; Schwarz, H. J. Am. Chem. Soc. 1989, 111, 9018. 
(c) Karrass, S.; Eller, K.; Schwarz, H. Chem. Ber. 1990, 123, 939.

11. Prusse, T.; Scliwarz, H. Orgunumetallics 1989, 8, 2851.

12. (a) Schulze, C.; Schwarz, H. Chimia 1987, 41, 29. (b) Schulze, C.; Schwarz, H.; Peak, D. A.; Gross، M. L. J. Am. Chem. Soc. 1987, 109, 2368. (c) Schulze, C.; Schwarz, H. J. Am. Chem. Soc. 1988, 110, 67. (d) Schulze, C.; Weiske, T.; Schwarz, H. Organometallics 1988, 7, 898.

13. Steinruck, N.; Schwarz, H. Organometallics 1989, 8, 759.

14. Sichroder, D.; Schwarz, H. I. Am. Chem. Soc. 1990, 112, 5947.

15. Chen, L. Z.; Miller, J. M. J. Am. Soc. Mass Spectrom. 1991, 2, 120 .

16. Chen, L. Z.; Miller, J. M. Can J. Chem., in press.

17. Chen, L. Z.; Miller, J. M. Org. Mass Spectrom., 1992, 27, 19.

18. Prusse, T.; Drewello, T.; Lebrilla, C. B.; Schwarz, H. J. Am. Chem. Soc. 1989, 111, 2857.

19. Holmes, J. L. Org. Mass Spectrom. 1985, 20, 169.

20. Chen, L. Z; Miller, J. M. Unpublished results.

21. Ciekey, D.; Dreweloo, T.; Eller, K.; Zummack, W.; Schwarz, H. Organometallics 1989, 8, 2439.

22. Eller, K.; Schwarz, H. Organometallics 1989, 8, 1820.

23. (a) Wentrup, C. Top. Curr. Chem. 1976, 62, 173. (b) Wentrup, C. Reactive Molecules; Wiley: New York, 1984.

24. Hattch, R. C; Jackson, T. C.; Stanko, E. M.; Freiser, B. S. I. Am. Chem. Soc. 1986, 108, 5086.

25. Eller, K.; Drewello, T.; Zummack, W.; Allspack, T.; Annen, U.; Regitz, M.; Schwarz, H. J. Am. Chem. Soc. 1989, 111, 4228 .

26. (a) Eller, K.; Schwarz, H. Chem. Bor. 1990, 123, 201. (b) Eller, K.; Drewello, T.; Schwarz, H. Organometallics 1987, 6, 2450.

27. (a) Armentrout, P. B.; Halle, L. F; Beauchamp, J. L. J. Am.
Chem. Soc. 1981, 103, 6624. (b) Jacobson, D. B.; Freiser, B. S. J. Am. Chem. Soc. 1983, 105, 7484.

28. Eller, K.; Zummack, W.; Schwarz, H. J. Am. Chem. Soc. 1990, 112, 621.

29. (a) Huang, S. K.; Allison, J. Organometallics 1983, 2, 833. (b) Tombarski, A.; Allison, J. Int. J. Mass Spectrom. Ion Phys. 1983, 49, 281. (c) Tsarbopoulos, A.; Allison, J. Organometallics 1984, 3, 86. (d) Tsarbopoulos, A.; Allison, J. J. Am. Chem. Soc. 1985, 107, 5085. (e) Chen, L. Z.; Miller, J. M. J. Am. Chem. Soc, submitted.

30. Aue, D. H.; Bowers, M. T. In Gas Phase Ion Chemistry, vol. 2; Bowers, M. T., Ed.; Academic: New York, 1977.

31. (a) Allison, J.; Ridge, D. P. J. Organomet. Chem. 1975, 99 , c11. (b) Allison, J.; Ridge, D. P. J. Am. Chem. Soc. 1976, 98, 7445 .

23. (a) Larrivee, M. L.; Allison, I. I. Am. Chem. Soc. 1990, 112, 7134. (b) Larsen, B. S.; Ridge, D. P. J. Am. Chem. Soc. 1984, 106, 1912.

33. (a) Jacobson, D. B.; Freiser, B. S. J. Am. Chem. Soc. 1983, 105, 7484. (b) Huang, Y.; Freiser, B. S. I. Am. Chem. Soc. 1990, 112, 1682. (c) Huang, Y.; Hill, Y. D.; Freiser, B. S. J. Am. Chem. Soc. 1991, 113, 840.

34. Eller, K.; Zummack, W.; Schwarz, H.; Roth, J. M.; Freiser, B. S. I. Am. Chem. Soc. 1991, 113, 833.

35. Prusse, T.; Gzekay, C.; Schwarz, H. Chem. Ber. 1991, 124, 141.

36. (a) Armentrout, P. B.; Halle, L. F.; Beauchamp, J. L. J. Am. Chern. Soc, 1981, 103, 6501. (b) Babinec, S. J.; Allison, J. J. Am. Chem. Soc. 1984, 106, 7718.

37. Weast, R. C. CRC Handbook of Chemistry and Physics, 65th ed.; CRC: Boca Raton, FL, 1984.

38. Armentrout, P. B.; Beauchamp, J. L. J. Am. Chem, Soc. 1980, 102, 1736. 